\title{
TINGKAT PENGETAHUAN PERAWAT TENTANG INFORMED CONSENT BAGI TENAGA PERAWAT YANG MELAKSANAKAN ASUHAN KEPERAWATAN UNTUK PASIEN YANG DIRAWAT DI RSUD Dr H SOEWONDO KENDAL
}

\author{
Kawi, Resti Nurhayati,SH. M.hum. dan Dr.Sofwan Dahlan,Sp.F \\ kawi@gmail.com \\ Magister Hukum Kesehatan \\ Universitas Katolik Soegijapranata Semarang
}

\begin{abstract}
ABSTRAK
Meningkatnya kesadaran masyarakat akan hak yang dimiliki merupakan salah satu indikator positif meningkatnya kesadaran hukum dalam masyarakat. Namun ada konsekensinya yaitu adanya kecenderungan meningkatnya kasus tenaga kesehatan ataupun rumah sakit di somasi,. Pokok permasalahan adalah tidak setiap upaya pelayanan kesehatan khususnya tindakan keperawatan hasilnya selalu memuaskan semua pihak terutama pasien.

Tingginya tuntutan masyarakat akan mutu pelayanan kesehatan sering kali menimbulkan ketidak puasan masyarakat terhadap pelayanan kesehatan terutama tindakan keperawatan yang dilakukan pada pasien yang dirawat. Hal ini tingkat pengetahuan tentang informed consent bagi perawat sangat penting untuk dapat memberikan pelindungan kepastian hukum kepada pemberi dan penerima pelayanan keperawatan.

Berdasarkan latar belakang masalah seperti tersebut di atas maka dirumuskan masalah penelitian yaitu bagaimana tingkat pengetahuan tentang informed consent para tenaga perawat yang melaksanakan asuhan keperawatan terhadap pasien yang dirawat di RSUD Dr. H .Soewondo Kendal ?Bagaimana pelaksanaan informed Consent oleh tenaga perawat yang melaksanakan asuhan keperawatan terhadap pasien di unit-unit rawat nginap Rumah Sakit Dr. H. Soewondo Kendal ?

Tujuanya untuk mengetahui tingkat pengetahuan tentang informed consent oleh tenaga perawat yang melakukan tindakan asuhan keperawatan bagi pasien yang dirawat di Rumah Sakit Dr. H. Soewondo Kendal. Untuk mengetahui pelaksanaan informed consent oleh tenaga perawat yang melakukan tindakan asuhan keperawatan bagi pasien yang dirawat di unit-unit Rumah Sakit Dr.H. Soewondo Kendal.

Metode penelitian yaitu yuridis sosiologis dengan responden 55 perawat yang melakukan tindakan asuhan keperawatan dengan metode survy dengan cara membagikan daftar pertanyaan tentang, pengetahuan informed consent, pengetahuan tentang kelengkapan informed cansent dan pengetahuan tentang pelaksanaan informed consent.

Kesimpulannya bahwa tingkat pengetahuan tentang informed consent,pengetahuan tentang kelengkapan informed consent, dan pengetahuan tentang pelaksanaan informed consent bagi tenaga perawat yang melakukan asuhan keperawatan untuk pasien yang dirawat di RSUD Dr H Soewondo masih kurang
\end{abstract}

Kata Kunci : Pengetahuan, perawat, informed consent.. 


\section{LATAR BELAKANG}

Meningkatnya kesadaran masyarakat akan hak yang dimiliki merupakan salah satu indikator positip meningkatnya kesadaran hukum dalam masyarakat . Namun ada konsekensinya yaitu adanya kecenderungan meningkatnya tenaga kesehatan ataupun rumah sakit disomosi . Adapun pokok permasalahan yaitu tidak setiap upaya pelayanan kesehatan khususnya tindakan keperawatan hasilnya selalu memuaskan semua pihak terutama pasien. Berdasarkan fenomena di atas, peneliti tertarik membuat proposal penelitian yang berjudul: "Tingkat Pengetahuan tentang Informed Consent bagi Tenaga Perawat yang Melaksanakan Tindakan Asuhan Keperawatan untuk Pasien yang Dirawat di RSUD Dr. H. Soewondo Kendal”.

\section{PERUMUSAN MASALAH}

Berdasarkan latar belakang masalah seperti tersebut di atas maka dirumuskan masalah penelitian yaitu :

1. Bagaimana tingkat pengetahuan tentang informed consent para tenaga perawat yang melaksanakan asuhan keperawatan terhadap pasien yang dirawat di RSUD Dr. H .Soewondo Kendal ?

2. Bagaimana pelaksanaan informed Consent oleh tenaga perawat yang melaksanakan asuhan keperawatan terhadap pasien di unit-unit rawat nginap RSUD Dr. H. Soewondo Kendal ?

\section{BATASAN MASALAH}

Berdasarkan rumusan masalah maka batasan masalahnya adalah

1. Tingkat pengetahuan tentang informed consent perawat yang melaksanakan tindakan asuhan keperawatan di RSUD Dr. H. Soewondo Kendal yang terdiri dari pengertian informed consent dan kelengkapan informed consent.

2. Serta pelaksanaan informed consent bagi tenaga perawat yang melaksanakan tindakan asuhan keperawatan kepada pasien yang di rawat di RSUD Dr. H. Soewondo Kendal.

\section{TUJUAN PENELITIAN}

1. Tujuan Umum

a. Untuk mengetahui tingkat pengetahuan tentang informed consent oleh tenaga perawat yang melakukan tindakan asuhan keperawatan bagi pasien yang dirawat di RSUD Dr. H. Soewondo Kendal.

b. Untuk mengetahui pelaksanaan informed consent oleh tenaga perawat yang melakukan tindakan asuhan keperawatan bagi pasien yang dirawat di unit-unit RSUD Dr.H. Soewondo Kendal

2. Tujuan Khusus

Untuk mengetahui pengertian informed consent bagi tenaga perawat yang melakukan tindakan asuhan keperawatan di RSUD Dr. H. Soewondo Kendal

a. Untuk mengetahui kelengkapan informed consent. Bagi tenaga perawat yang melakukan tindakan keperawatan di RSUD Dr H Soewondo Kendal

b. Untuk mengetahui siapa yang melaksanakan persetujuan informed consent pada tindakan asuhan keperawatan di RSUD Dr.H. Soewondo Kendal 


\section{MANFAAT PENELITIAN}

b. Bagi Departemen Kesehatan, hasil penelitian ini bisa digunakan sebagai bahan masukan dalam membuat kebijakan yang menyangkut tentang persetujuan tindakan keperawatan dimasa yang akan datang.

c. Bagi pimpinan rumah sakit, hasil penelitian ini dapat digunakan sebagai sarana untuk mengendalikan mutu pelayanan kesehatan yang telah diberikan dan untuk memonitor serta mengevaluasi sejauh mana persetujuan tindakan keperawatan telah diterapkan di rumah sakit yang dipimpinannya, kemudian menentukan langkah-langkah yang akan diambil dalam meningkatkan kualitas pebuatan persetujuan tindakan keperawatan.

d. Bagi tenaga keperawatan, hasil penelitian ini bisa dipakai sebagai alat untuk introspeksi diri, sejauh mana memberikan informasi kepada pasiennya sebelum menandatangani formulir informed consent serta melakukan tindakan keperawatan.

e. Bagi pengguna jasa pelayanan kesehatan, hasil penelitian ini akan memberikan gambaran sejauh mana informed consent sebagai alat bukti hukum yang tertulis oleh para tenaga perawat dalam memberikan pelayanan kepada masyarakat.

\section{METODE PENELITIAN}

\section{Metode Pendekatan}

Metode pendekatan yang digunakan adalah metode pendekatan Yuridis Sosiologis. Hal ini karena data yang dipergunakan adalah data primer dengan metode wawancara kepada tenaga perawat yang bertugas di unitunit rawat nginap RSUD Dr. H. Soewondo Kendal yang melakukan tidakan asuhan keperawatan dengan mengingat bahwa permasalahan berkisar tentang tingkat pengetahuan informed consent bagi tenaga perawat yang melaksanakan tindakan asuhan keperawatan untuk pasien yang dirawat RSUD Dr Soewondo Kendal.

\section{Spesifikasi Penelitian}

Spesifikasi penelitian ini secara deskriptif analitis artinya menggambarkan ruang lingkup yang luas sekaligus memberikan batasan-batasan yang tegas yang didiskripsikan dan keadaan di lapangan Analisis tentang pengetahuan informed consent bagi tenaga perawat yang melaksanakan tindakan asuhan keperawatan untuk pasien yang dirawat di unit -unit rawat nginap RSUD. Dr. H. Soewondo Kendal.

\section{Populasi dan Sampel}

Populasi adalah seluruh obyek atau seluruh individu atau seluruh gejala atau seluruh kejadian atau seluruh unit yang akan diteliti. Populasi dalam penelitian ini adalah tenaga perawat yang melaksanakan tindakan asuhan keperawatan dengan mendokumentasi informed concent pasien yang mendapat tindakan keperawatan. di ruang unit-unit rawat nginap. RSUD. Dr. H. Soewondo Kendal.

Sampel adalah bagian dari populasi dengan karekteristik tertentu yang hendak diteliti. Metode penarikan sampel yang dilakukan dengan cara total sampel mengingat tenaga perawat di unit-unit rawat nginap RSUD Dr. H. Seowondo Kendal jumlahnya 55 perawat.

\section{Responden}

Responden dalam penelitian ini : Perawat di rawat nginap RSUD Dr. H. Soewondo Kendal yang melakukan tindakan asuhan keperawatan dengan mengunakan format informed consent, dalam penelitian ini dilakukan total sampling dengan kreteria:1) perawat yang melaksanakan asuhan keperawatan, 2) perawat yang merupakan pegawai tetap di RSUD Dr. H Soewondo Kendal. 


\section{Metode Pengumpulan data}

1. Studi lapangan dilakukan dengan :

a. Teknik wawancara dengan menggunakan daftar pertanyaan (quesioner) yang bersifat tertutup yaitu cara untuk memperoleh informasi dengan bertanya langsung pada responden. Dengan wawancara diharapkan akan diperoleh jawaban yang luas dan mendalam.

b. Observasi langsung kepada responden yakni dengan melihat secara langsung responden yang sedang mengadakan kegiatan tentang proses pembjuatan persetujuan tindakan medis atau tindakan keperawatan atau informed consent di ruang rawat nginap di RSUD Dr. H Soewondo Kendal kepada seorang pasien sehingga memperoleh keadaan yang terjadi pada saat tenaga perawat yang sedang melaksanakan informed consent.

2. Study kepustakaan bertujuan untuk memperoleh data sekunder yaitu bahan-bahan pustaka yang berhubungan erat dengan permasalahan yang terdapat dalam penelitian.

a. Bahan hukum primer adalah bahan hukum yang bersifat mengikat, yaitu

1. Undang-undang Nomor 4 tahun 2009 tentang Rumah Sakit.

2. Undang-Undang Nomor 36 Tahun 2009 tentang Kesehatan.

3. Peraturan Pemerintah Nomor 32 tahun 1996 tentang Tenaga Kesehatan.

4. Peraturan Menteri Kesehatan Republik Indonesia Nomor 290/MENKES/PER/III/2008 tentang Persetujuan Tindakan Kedokteran.

5. Keputusan Menteri Kesehatan Nomor 123 / MENKES / SK / 11/2001 tentang Registrasi dan Praktek Perawat.

6. Peraturan Menteri Kesehatan Republik Indonesia Nomor HK.02.02/MENKES/148/2010 tentang Ijin dan Penyelenggaraan Praktik Perawat.

7. Peraturan Bupati Kendal Nomor 40 tahun 2009 tentang peraturan internal RSUD H. Soewondo Kendal

8. Surat Keputusan Direktur RSUD H. Soewondo Kendal nomor 441.6/051/RSUD/2008 tentang Standar prosedur tindakan keperawatan.

b. Bahan hukum sekunder adalah bahan hukum yang erat hubungannya dengan bahan hukum primer dan dapat membantu menganalisa dan memahami bahan hukum primer, yaitu buku-buku tentang Etika Profesi Keperawatan, Dasar-Dasar Keperawatan Profesional, Pengantar Statistik Keperawatan, Pendidikan dan Perilaku, Metodologi Penelitian.

c. Bahan hukum tersier adalah bahan yang memberikan informasi tentang bahan hukum primer dan sekunder, yaitu Kamus Bahasa Indonesia, Kamus Bahasa Inggris, Kamus Hukum, Kamus Kedokteran, Kapita Selekta Kedokteran.

\section{Lokasi Penelitian dan kurun waktu penelitian}

Penelitian ini akan mengambil lokasi di ruang unit-unit rawat nginap RSUD Dr. H. Soewondo Kendal. Penelitian dilaksanakan pada bulan April sampai dengan Mei 2010.

\section{Metode Analisa Data}

Metode analisis data yang digunakan dalam penelitian ini adalah metode kualitatif normatif. Metode kualitatif normatip yaitu dengan menganalisa data yang ada untuk dikaitkan dengan teori-teori, konsep-konsep, doktrin-doktrin dari para ahli serta didasarkan pada peraturan perundang-undangan. Dalam menganalisa data sekunder tersebut, penguraian data dapat disajikan dalam bentuk kalimat yang konsisten, logis dan efektif serta sistematis sehingga mempermudah untuk diinterprestasi data dan konstruksi data serta pemahaman akan analisis yang dihasilkan, yaitu mencari sebab akibat dari suatu masalah dan menguraikannya 
secara konsisten, sistematis dan logis sesuai dengan perumusan masalah yang menjadi fokus dalam penelitian.

\section{PENYAJIAN THESIS}

Rancangan penyajian tesis memuat rancangan sistematika penulisan tesis yaitu Bab I Pendahuluan mengandung bab-bab latar belakang masalah, perumusan masalah, masalah, tujuan, manfaat, metode, metode penelitian, Bab II Tinjauan Pustaka adalah uraian sistematis tentang kata-kata kunci yang dikumpulkan dari perpustakaan, yang ada hubungannya dengan judul dan perumusan masalah untuk mencapai tujuan penelitian, Bab III Hasil Penelitian dan pembahasan bab ini memuat hasil penelitian dan pembahasan yang sifatnya terpadu dan tidak dipecah menjadi sub bab terendiri. Hasil penelitian sedapat-dapatnya disajikan dalam bentuk table, grafik, gambar, atau bentuk lain, dan ditempatkan sedekat-dekatnya dengan pembahasan, agar pembaca lebih mudah mengikuti urian. Pembahasan, tentang hasil yang diperoleh, berupa penjelasan teoretik, baik secara kualitatif, kuantitatif, atau secara statistic.

\section{TINJAUAN PUSTAKA}

\section{PENGETAHUAN}

\section{Pengertian Pengetahuan}

Pengetahuan merupakan hasil dari tahu dan ini terjadi setelah orang melakukan pengindraan terhadap suatu obyek. Pengindraan terjadi melalui panca indra manusia, yaitu indra penglihatan, pendengaran, rasa, raba, dan penciuman. Sebagian besar pengetahuan manusia diperoleh melalui mata dan telinga. Pengetahuan atau kognitif merupakan domain yang sangat penting terbentuknya tindakan seorang.

2. Tingkatan Pengetahuan

Menurut Notoatmojo ${ }^{1}$ pengetahuan seseorang mempunyai enam tingkatan:

a. Tahu (Know)

b. Tahu diartikan sebagai mengingat sesuatu materi yang telah dipelajari. Termasuk dalam pengetahuan tingkat ini adalah mengingat kembali (recall) terhadap sesuatu yang telah dipelajari atau rangsangan yang telah diterima sebelumnya.

c. Memahami (Comprehension)

d. Memahami diartikan sebagai sesuatu kemampuan untuk menjelaskan secara benar tentang obyek yang diketahui dan dapat menginterprestasikan materi tersebut secara benar.

e. Aplikasi (Aplication)

f. Aplikasi diartikan sebagai kemampuan untuk menggunakan materi yang telah dipelajari pada situasi atau kondisi yang berbeda.

g. Analisis (Analysis)

h. Analis adalah suatu kemampuan untuk menjabarkan materi atau suatu obyek kedalam komponen-komponen yang terdapat dalam suatu masalah

i. Sintesis (Synthesis)

j. Sintesis menunjukan kepada suatu kemampuan untuk menghubungkan atau merangkum formulasi yang ada menjadi baru.

k. Evaluasi (Evaluation)

I. Evaluasi ini berkaitan kemampuan untuk melakukan penilaian terhadap suatu materi atau obyek .

\footnotetext{
${ }^{1}$ Notoadmodjo, Soekidjo,2003, Pendidikan dan Perilaku. Jakarta : Rineka hal 8
} 


\section{TENAGA PERAWAT}

1. Tenaga Kesehatan

Dalam Pasal 1 ayat (3) Perturan Pemerintah no 32 tahun 1996 tentang. Tenaga kesehatan adalah setiap orang yang mengabdikan diri dalam bidang kesehatan serta memiliki pengetahuan dan atau keterampilan melalui pendidikan di bidang kesehatan yang untuk jenis tertentu memerlukan kewenangan untuk melakukan upaya kesehatan. Demikian pula dalam Pasal 2 Peraturan Pemerintah no. 32 tahun 1996 tentang Tenaga Kesehatan disebutkan bahwa tenaga kesehatan adalah :

a. Tenaga kesehatan terdiri dari :

1. tenaga medis;

2. tenaga keperawatan;

3. tenaga kefarmasian;

4. tenaga kesehatan masyarakat;

5. tenaga gizi;

6. tenaga keterapian fisik;

7. tenaga keteknisian medis.

b. Tenaga medis meliputi dokter dan dokter gigi.

c. Tenaga keperawatan meliputi perawat dan bidan.

d. Tenaga kefarmasian meliputi apoteker, analis farmasi dan asisten apoteker.

e. Tenaga kesehatan masyarakat meliputi epidemiolog kesehatan, entomolog kesehatan, mikrobiolog kesehatan, penyuluh kesehatan, administrator kesehatan dan sanitarian.

f. Tenaga gizi meliputi nutrisionis dan dietisien.

g. Tenaga keterapian fisik meliputi fisioterapis, okupasiterapis dan terapis wicara.

h. Tenaga keteknisian medis meliputi radiografer, radioterapis, teknisi gigi, teknisi elektromedis, analis kesehatan, refraksionis optisien, otorik prostetik, teknisi transfusi dan perekam medis.

Adapun tugas tenaga kesehatan diatur dalam Pasal 23 ayat (2) Undang-undang No. 36 tahun 2009 tentang Kesehatan yang berbunyi Kewenangan untuk menyelenggarakan pelayanan kesehatan sebagaimana dimaksud pada ayat (1) dilakukan sesuai dengan bidang keahlian yang dimiliki. Dalam menjalankan tugasnya tenaga kesehatan juga harus memberikan perlindungan kepada pasien yang secara hukum diatur dalam Pasal 56 ayat (1) Undang-undang no. 36 tahun 2009 yang menyatakan Setiap orang berhak menerima atau menolak sebagian atau seluruh tindakan pertolongan yang akan diberikan kepadanya setelah menerima dan memahami informasi mengenai tindakan tersebut secara lengkap. PERMENKES 290/MENKES/PER/III/2008 Pasal 10 Ayat 3 Tenaga tertentu dapat membantu memberikan penjelasan sesuai dengan kewenangannya, Ayat 4 Tenaga kesehatan tertentu sebagaimana dimaksud pada ayat (3) adalah tenaga kesehatan yang ikut memberikan pelayanan kesehatan secara langsung kepada pasien.

Keperawatan adalah pelayan profesional yang merupakan bagian integral dari pelayanan kesehatan berdasarkan ilmu dan kiat keperawatan, berbentuk pelayanan biopsiko-sosial-spiritual yang menyeluruh ditujukan kepada individu, kelompok dan masyarakat baik sehat maupun sakit yang mencakup seluruh kehidupan manusia.

2. Pengertian Perawat

Perawat adalah seseorang yang telah menyelesaikan suatu program pendidikan dasar perawatan dan diberi wewenang oleh pemerintah serta memenuhi syarat untuk memberikan pelayanan perawatan bermutu dan penuh tanggung jawab. ${ }^{2}$

${ }^{2}$ Ali, Zaidin, 1998. Dasar-Dasar Keperawatan Profisional, Jakarta : Widya Medika, hal 10. 


\section{a. Peran Perawat}

Peran adalah seperangkat tingkah laku yang diharapkan oleh orang lain terhadap seseorang sesuai kedudukannya dalam suatu system. Peran dipengaruhi oleh keadaan sosial baik dari dalam maupun dari luar dan dapat bersifat stabil. Peran adalah bentuk dari perilaku yang diharapkan dari seseorang pada situasi tertentu. Peran perawat yang dimaksud adalah cara untuk menyatakan aktivitas dalam praktik, dimana telah menyelesaikan pendidikan formalnya yang diakui dan diberi kewenangan oleh pemerintah untuk menjalankan tugas dan tanggung jawab keperawatan secara profesional sesuai dengan kode etik profesional.

Peran perawat

1. Memberikan pelayanan keperawatan kepada individu, keluarga, kelompok, atau masyarakat sesuai diagnosa masalah yang terjadi mulai dari masalah yang bersifat sederhana sampai pada masalah yang kompleks.

2. Memperhatikan individu dalam konteks sesuai kehidupan klien, perawat harus memperhatikan klien berdasarkan kebutuhan signifikasi dari klien.

\section{b. Fungsi Perawat}

Fungsi adalah pekerjaan yang harus dilaksanakan sesuai dengan perannya. Adapun fungsi perawat :

1. Observasi gejala dan respon pasien yang berhubungan dengan penyakit dan penyebabnya;

2. Memantau pasien, menyusun, dan memperbaiki rencana keperawatan secara terus menerus berdasarkan pada kondisi dan kemampuan pasien;

3. Supervisi semua pihak yang ikut terlibat dalam perawatan pasien;

4. Mencatat dan elaporkan keadaan pasien;

5. Melaksanakan prosedur fdan teknik kesehatan;

6. Memberikan pengarahan dan penyuluhan untuk meningkt kesehatan fisik dan mental;

7. Sebagai anggota tim kesehatan, perwatan bekerja dalam merencanakan dan melaksanakan program kesehatan yang mencakup pencegahan penyakit, peningkatana kesehatan, penyembuhan, dan rehabilitasi;

c. Tugas Perawat

Tugas perawat melakukan pekerjaan sesuai dengan keahlian dan ketrampilan yang dimiliki berdasarkan ilmu pengetahuan yang dimilikinya.

1. Bertanggung jawab membantu klien dan keluarga dalam menginterpretasikan informasi dari berbagai pemberi pelayanan dan dalam memberikan informasi laian yang diperlukan untuk mengambil persetujuan (informed consent) atas tindakan keperawatan yang diberikan kepadanya.

2. Mempertahankan dan melindungi hak-hak klien, harus dilakukan karena klien yang sakit dan dirawat di rumah sakit akan berinteraksi dengan banyak petugas kesehatan. Perawat adalah anggota tim kesehatan yang paling lama kontak dengan klien, sehingga diharapkan perawat harus mampu membela hak-hak klien.

d. Hak dan Kewajiban Perawat

Hak dan kewajiban Perawat ditentukan dalam Permenkes Nomor HK.02.02/MENKES/148/1/2010 pasal 11 tentang Hak perawat sebagai berikut :
a) Memperoleh perlindungan hukum dalam melaksanakan praktik keperawatan sesuai standar
b) Memperoleh informasi yang lengkap dan jujur dari klien dan / atau keluarganya
c) Melaksanakan tugas sesuai dengan kompetensi 
d) Menerima imbalan jasa profesi dan

e) Memperoleh jaminan perlindungan terhadap resiko kerja yang berkaitan dengan tugasnya

Adapun Kewajiban Perawat terdapat dalam pasal 12 terdiri dari :

a) Menghoramti hak pasien

b) Melakukan rujukan

c) Menyimpan rahasia sesuai dengan peraturan perundang-undangan

d) Memberikan informasi tentang masalah kesehatan pasien/klien dan pelayanan yang dibutuhkan

e) Meminta persetujuan tindakan keperawatan yang akan dilakukan

f) Melakukan pencatatan asuhan keperawatan secara sistematis dan

g) Mematuhi standar

\section{INFORMED CONSENT}

1. Pengertian Informed Concent

a. Menurut Jacobalis ${ }^{3}$, Informed terkait dengan informasi atau penjelasan. Consent artinya persetujuan, atau lebih 'tajam' lagi, "izin". Jadi informed consent adalah persetujuan atau izin oleh pasien atau keluarga yang berhak kepada dokter untuk melakukan tindakan medis pada pasien, seperti pemeriksaan fisik dan pemeriksaan lain-lain untuk menegakkan diagnosis, memberi obat, melakukan suntikan, menolong bersalin, melakukan pembiusan, melakukan pembedahan, melakukan tindak-lanjut jika terjadi kesulitan. Dengan demikian, informed consent adalah persetujuan atau izin oleh pasien atau keluarga yang berhak kepada dokter untuk melakukan tindakan medis atas dirinya, setelah kepadanya oleh dokter yang bersangkutan diberikan informasi/penjelasan yang lengkap tentang tindakan. Mendapat penjelasan lengkap terhadap tindakan yang akan dilakukan adalah salah satu hak pasien yang diakui oleh undang-undang dengan kalimat pendek, informed consent adalah Persetujuan Setelah Penjelasan (PSP). ${ }^{4}$

b. Menurut Komalawati dalam Irwandy, informed consent dirumuskan sebagai suatu kesepakatan/persetujuan pasien atas upaya medis yang akan dilakukan dokter terhadap dirinya setelah memperoleh informasi dari dokter mengenai upaya medis yang dapat dilakukan untuk menolong dirinya disertai informasi mengenai segala resiko yang mungkin terjadi. Mengenai informed consent (persetujuan) masih diperlukan pengaturan hukum lebih lengkap. Karena tidak hanya untuk melindungi pasien dari kesewenangan dokter, tetapi juga diperlukan untuk melindungi dokter dari kesewenangan pasien yang melanggar batas-batas hukum dan perundang-undangan (malpraktek) ${ }^{5} \mathrm{Di}$ Indonesia terdapat ketentuan informed consent yang diatur antara lain pada Peraturan Pemerintah No 18 tahun 1981 dan Surat Keputusan PB IDI No 319/PB/A4/88 ${ }^{6}$ Pernyataan IDI tentang informed consent tersebut antara lain :

1) Manusia dewasa sehat jasmani dan rohani berhak sepenuhnya menentukan apa yang hendak dilakukan terhadap tubuhnya. Dokter tidak berhak melakukan tindakan medis yang bertentangan dengan kemauan pasien, walaupun untuk kepentingan pasien sendiri.

3 Jacobalis,S.2005 Informed Consent Persetujuan Tindakan Medis .Retrived Juni 24, 2005 From:http://www.sinarharapan.co.id/iptek/kesehatan/2005/0624/kes3.html

4 Any Isfandyarie,2006 Tanggung Jawab Hukum dan Sangsibagi Dokter, Prestasi Pustaka,Jakarta hal 13

5 Hidayat, T. 2007. Perlu Diungkap Hak dan Kewajiban Pasien . Retrieved Desember 28, 2007. from http://www.duniaesai.com/hukum/hukumg.html

6 Indradi, R. 2007. Informed Consent, Hak-Hak Pasien dalam Menyatakan Persetujuan Rencana Tindakan Medis. Retrieved Januari 25, 2007. from http://ranocenter.blogspot.com/2007_01_01_archive.html 
2) Semua tindakan medis (diagnotik, terapeutik maupun paliatif) memerlukan informed consent secara lisan maupun tertulis.

3) Setiap tindakan medis yang mempunyai risiko cukup besar, mengharuskan adanya persetujuan tertulis yang ditandatangani pasien, setelah sebelumnya pasien memperoleh informasi yang adekuat tentang perlunya tindakan medis yang bersangkutan serta risikonya.

4) Untuk tindakan yang tidak termasuk dalam butir 3, hanya dibutuhkan persetujuan lisan atau sikap diam

5) Informasi tentang tindakan medis harus diberikan kepada pasien, baik diminta maupun tidak diminta oleh pasien. Menahan informasi tidak boleh, kecuali bila dokter menilai bahwa informasi tersebut dapat merugikan kepentingan kesehatan pasien. Dalam hal ini dokter dapat memberikan informasi kepada keluarga terdekat pasien. Dalam memberi informasi kepada keluarga terdekat dengan pasien, kehadiran seorang perawat/paramedik lain sebagai saksi adalah penting.

6) Isi informasi mencakup keuntungan dan kerugian tindakan medis yang direncanakan, baik diagnostik, terapeutik maupun paliatif. Informasi biasanya diberikan secara lisan, tetapi dapat pula secara tertulis (berkaitan dengan informed consent).

c. Dalam Konsil Kedokteran Indonesia $(\mathrm{KKI})^{7}$ persetujuan tindakan kedokteran atau kedokteran gigi yang sering disebut juga informed consent, merupakan persetujuan pasien atau yang sah mewakilinya atas rencana tindakan kedokteran atau kedokteran gigi yang diajukan oleh dokter atau dokter gigi, setelah menerima informasi yang cukup untuk dapat membuat persetujuan. Persetujuan tindakan kedokteran ini merupakan pernyataan sepihak dari pasien dan bukan perjanjian antara pasien dengan dokter atau dokter gigi, sehingga dapat ditarik kembali setiap saat persetujuan tindakan kedokteran dan kedokteran gigi merupakan proses sekaligus hasil dari suatu komunikasi yang efektif antara pasien dengan dokter atau dokter gigi dan bukan sekedar penandatanganan formulir persetujuan.

d. Informed Consent adalah sebuah izin khusus atau formulir pemberian kuasa, diperlukan untuk suatu diagnosa tidak biasa atau prosedur terapi yang dilakukan terhadap pasien. Formulir ini menyediakan bukti tertulis bahwa pasien menyetujui prosedur - prosedur yang tercantum dalam pemberian kuasa. Supaya izin tersebut sah, dokter harus memberitahukan tentang prosedur yang dilakukan, resiko-resiko, prosedur alternative dan hasil yang mungkin didapat dengan pasien dan/atau wali pasien. Syarat keikutsertaan atau partisipasi (Conditions of Participation ) yang membutuhkan staf medis, yang sesuai dengan peraturan dan ketentuan menyatakan bahwa sebuah operasi bedah hanya bisa dilakukan atas seijin pasien atau wakil yang sah, kecuali dalam keadaan darurat. Sebuah formulir pengesahan izin operasi juga harus terlampir dalam catatan medis pasien sebelum operasi bedah dilakukan. ${ }^{8}$

e. Informed Consent adalah izin tertulis yang dibuat secara sadar dan sukarela dari pasien diperlukan sebelum suatu pembedahan dilakukan. Izin tertulis seperti itu melindungi pasien terhadap pembedahan yang lalai dan melindungi ahli bedah terhadap tuntutan dari suatu lembaga hukum. Demi kepentingan semua pihak yang terkait, perlu mengikuti prinsip medikolegal yang baik. Sebelum pasien menandatangani formulir consent, ahli bedah harus memberikan penjelasan yang jelas dan sederhana tentang apa yang akan diperlukan dalam pembedahan. Ahli bedah juga harus menginformasikan pasien tentang alternatif-alternatif yang ada, kemungkinan risiko, komplikasi, perubahan bentuk tubuh,

7 Konsil Kedokteran Indonesia. 2006. Manual Persetujuan Tindakan Medis. Edisi I. Jakarta : Konsil kedokteran Indonesia.hal 18

8 Brunner \& Suddarth, 2002. Keperawatan Medical Bedah, EGC, Jakarta 
menimbulkan kecacatan, ketidakmampuan, dan pengangkatan bagian tubuh, juga tentang apa yang diperkirakan terjadi pada periode pascaoperatif awal dan lanjut.

2. Jenis Informed Consent

Menurut FKUI ${ }^{9}$ Persetujuan Tindakan Medis (Informed Consent) dapat diklasifikasikan menjadi 2, yaitu:

a. Implied Consent, yaitu persetujuan yang dianggap telah diberikan walaupun tanpa pernyataan resmi, yaitu pada keadaan biasa dan pada keadaan darurat atau emergency. Pada keadaan gawat darurat yang mengancam jiwa pasien, tindakan menyelamatkan kehidupan (life saving) tidak memerlukan Informed Consent.

b. Expressed Consent, yaitu persetujuan tindakan medis yang diberikan secara eksplisit, baik secara lisan (oral) maupun tertulis (written).

Menurut Sanjoyo ${ }^{10}$ pasien memiliki hak untuk memperoleh atau menolak pengobatan dan terdapat beberapa jenis persetujuan antara lain :

1) Ijin langsung (express consent): pasien atau wali segera menyetujui usulan pengobatan yang ditawarkan dokter atau pihak RS (bisa lisan atau tertulis)

2) Ijin secara tidak langsung (implied consent): tindakan pengobatan dilakukan dalam keadaan darurat yang dilakukan untuk menyelamatkan jiwa pasien

3) Persetujuan khusus : pasien wajib mencantumkan pernyataan bahwa kepadanya telah diberikan penjelasan suatu informasi terhadap apa yang akan dilakukan oleh tim medis terhadap pasien. Pada informed consent, pasien sendiri yang harus menandatangani persetujuan kecuali pasien tersebut tidak mampu atau mempengaruhi fungsi seksual atau reproduksi (suami/istri). ${ }^{11}$

\section{Saat diperlukan Informed Consent}

Dengan mengacu kepada anjuran General Medical Council (GMC) di Inggris, KKI memberikan petunjuk bahwa persetujuan tertulis atau informed consent diperlukan pada keadaankeadaan sebagai berikut :

1) Bila tindakan terapeutik bersifat kompleks atau menyangkut risiko atau efek samping yang bermakna;

2) Bila tindakan kedokteran tersebut bukan dalam rangka terapi;

3) Bila tindakan kedokteran tersebut memiliki dampak yang bermakna bagi kedudukan kepegawaian atau kehidupan pribadi dan sosial pasien;

4) Bila tindakan yang dilakukan adalah bagian dari suatu penelitian.

Rujukan di atas menjelaskan bahwa informed consent harus diberikan pada semua tindakan yang memiliki resiko atau efek samping yang bermakna. Hal mana juga terhadap tindakan medis yang dapat mengancam status kepegawaian atau kehidupan pribadi juga sosial. Contoh suatu tindakan medis yang dapat menimbulkan kecacatan sehingga sesorang harus kehilangan pekerjaan dan perikehidupan sosial dalam masyarakat. Pemberian informed

9 FKUI. 2007. Persetujuan Tindakan Medik (Informed Consent). Retrieved Desember 28, 2007. from http://fkuii.org/tiki-download_wiki_attachment.php

10 Sanjoyo,R. 2007. Aspek Hukum Rekam Medis. Retrieved Desember 28, 3007, from http://yoyoke.web.ugm.ac.id/download/aspekhukumrekam medis.pdf

${ }^{11}$ Konsil Kedokteran Indonesia. 2006. Manual Persetujuan Tindakan Medis. Edisi I. Jakarta : Konsil kedokteran Indonesia. 
consent juga harus diberikan pada suatu tindakan medis yang bukan dengan tujuan terapi, termasuk di dalamnya adalah untuk penelitian atau pendidikan.

Sementara menurut Brunner dan Suddarth ${ }^{12}$ dalam buku ajar Medical Bedah Informed Consent tindakan medis diperlukan pada saat;

1) Prosedur tindakan invasif seperti insisi bedah, biopsi, sistoskopi, atau parasentesis.

2) Tindakan yang menggunakan anestesi.

3) Prosedur non-bedah yang dilakukan di mana risikonya pada pasien lebih dari sekedar risiko ringan, seperti arteriogram.

4) Terapi radiasi.

Senada dengan General Medical Council (GMC) di Inggris, maka menurut Brunner dan Suddarth semua tindakan medis yang beresiko lebih dari resiko ringan harus diberikan informed consent baik tindakan medis terapetik maupun diganostik serta tindakan yang menggunakan anestesi.

4. Informasi yang Diberikan pada Pasien atau Keluarga

Menurut UU No. 29 Tahun 2004 tentang Praktik Kedokteran, Pasal 45 ayat (3) bahwa penjelasan sekurang-kurangnya mencakup :
a. Diagnosis dan tata cara tindakan medis;
b. Tujuan tindakan medis yang dilakukan;
c. Alternatif tindakan lain dan risikonya;
d. Risiko dan komplikasi yang mungkin terjadi;
e. Prognosis (perkiraan hasil) dari tindakan yang dilakukan;
f. Pembiayaan.

Konsil Kedokteran Indonesia ${ }^{13}$ bahwa dalam Pasal 45 UU Praktik Kedokteran memberikan batasan minimal informasi yang selayaknya diberikan kepada pasien, yaitu:
a. Diagnosis dan tata cara tindakan medis
b. Tujuan tindakan medis yang dilakukan
c. Alternatif tindakan lain dan risikonya
d. Risiko dan komplikasi yang mungkin terjadi
e. Prognosis terhadap tindakan yang dilakukan.

Dengan mengacu kepada kepustakaan, KKI memberikan 12 kunci informasi yang sebaiknya diberikan kepada pasien:
a. Diagnosis dan prognosis secara rinci dan juga prognosis apabila tidak diobati.
b. Ketidakpastian tentang diagnosis (diagnosis kerja dan diagnosis banding) termasuk pilihan pemeriksaan lanjutan sebelum dilakukan pengobatan.
c. Pilihan pengobatan atau penatalaksanaan terhadap kondisi kesehatannya, termasuk pilihan untuk tidak diobati.
d. Tujuan dari rencana pemeriksaan atau pengobatan, rincian dari prosedur atau pengobatan yang dilaksanakan, termasuk tindakan subsider seperti penanganan nyeri, bagaimana pasien seharusnya mempersiapkan diri, rincian apa yang akan dialami pasiens selama dan sesudah tindakan, termasuk efek samping yang biasanya terjadi dan yang serius.

\footnotetext{
12 Brunner \& Suddarth, 2002. Keperawatan Medical Bedah, EGC, JakartaBrunner \& Suddarth, 2002. Keperawatan Medical Bedah, EGC, Jakarta.

${ }^{13}$ Konsil Kedokteran Indonesia. 2006. Manual Persetujuan Tindakan Medis. Edisi I. Jakarta : Konsil kedokteran Indonesia.
} 
e. Untuk setiap pilihan tindakan, diperlukan keterangan tentang kelebihan/keuntungan dan tingkat kemungkinan keberhasilannya dan diskusi tentang kemungkinan risiko yang serius atau sering terjadi dan perubahan gaya hidup sebagai akibat dari tindakan tersebut.

f. Nyatakan bila rencana pengobatan tersebut adalah upaya yang masih eksperimental.

g. Bagaimana dan kapan kondisi pasien dan akibat sampingannya akan dimonitor atau dinilai kembali.

h. Nama dokter yang bertanggung jawab secara keseluruhan untuk pengobatan tersebut, serta bila mungkin nama anggota tim lainnya.

i. Bila melibatkan dokter yang sedang mengikuti pelatihan atau pendidikan, maka sebaiknya dijelaskan peranannya di dalam rangkaian tindakan yang akan dilakukan.

j. Mengingatkan kembali bahwa pasien dapat mengubah pendapatnya setiap waktu. Bila hal itu dilakukan maka pasien bertanggungjawab penuh atas konsekuensi pembatalan yang akan dilakukan.

k. Mengingatkan bahwa pasien berhak memperoleh pendapat kedua dari dokter lain.

I. Bila memungkinkan juga diberitahu tentang perincian biaya.

m. Mengingat Informed Consent tidak hanya suatu informasi dan persetujuan tetapi merupakan suatu komponen penting dalam memberikan suatu tindakan apapun yang kaitannya dengan perlindungan hukum bagi pemberi pelayanan kesehatan juga melindungi pasien dari hal-hal yang tidak diinginkan dan demi kepentingan semua pihak.

\section{Tujuan Penjelasan dalam Informed Consent}

Tujuan penjelasan yang lengkap sebelum disetujui tindakan medik adalah agar pasien menentukan sendiri keputusannya sesuai dengan pilihan dia sendiri (informed decision). Karena itu, pasien juga berhak untuk menolak tindakan medik yang dianjurkan. Pasien juga berhak untuk meminta pendapat dokter lain (second opinion), dan dokter yang merawatnya berbeda dengan di masa lalu - tidak boleh merasa tersinggung, apalagi langsung mengatakan, "silakan saudara mau ke dokter mana pun, tapi saya tidak bertanggung jawab lagi".

Dari uraian di atas maka tujuan memberikan penjelasan dalam informed consent adalah agar pasien dapat mengerti dan memahami tentang kondisinya sebelum mengambil suatu keputusan bagi dirinya. Hal tersebut juga memberikan kesempatan pada pasien untuk mempertimbangkan tentang keputusan yang akan diambil. Pasien juga dapat mempertimbangkan tentang alternatif lain dan bahkan melakukan second opinion. Sungguhpun demikian seorang dokter dituntut tetap memberikan penjelasan secara etis dengan cara komunikasi yang sebaik-baiknya sehingga pasien dan keluarganya tidak tersinggung.

6. Kewenangan Memberikan Informed Consent dan Cara Memberikan Informed Consent

Siapa yang berhak memberikan persetujuan atau menyatakan menolak tindakan medis. Pada dasarnya, pasien sendiri jika ia dewasa dan sadar sepenuhnya. Menurut penjelasan Pasal 45 UU No. 29/2004 tersebut di atas, apabila pasien sendiri berada di bawah pengampuan, persetujuan atau penolakan tindakan medis dapat diberikan oleh keluarga terdekat, antara lain suami/isteri, ayah/ibu kandung, anak-anak kandung atau saudara-saudara kandung. Dalam keadaan gawat darurat, untuk menyelamatkan jiwa pasien tidak diperlukan persetujuan. Namun, setelah pasien sadar atau dalam kondisi yang sudah memungkinkan, segera diberikan penjelasan dan dibuat persetujuan.

Cara memberikan informed consent dapat diberikan secara tertulis, secara lisan, atau secara isyarat. Dalam bahasa aslinya, yang terakhir ini dinamakan implied consent. Misalnya, jika pasien mengangguk atau langsung membuka baju jika dokter mengatakan, "Boleh saya memeriksa saudara?". Untuk tindakan medis dengan risiko tinggi (misalnya pembedahan atau 
tindakan invasif lainnya), persetujuan harus secara tertulis, ditandatangani oleh pasien sendiri atau orang lain yang berhak dan sebaiknya juga saksi dari pihak keluarga. FKUI. 2007. Persetujuan Tindakan Medik (Informed Consent). Retrieved Desember 28, 2007. from http://fkuii.org/tiki-download_wiki_attachment.php

Menurut FKUI ${ }^{14}$ berpedoman pada Permenkes No. 585 tahun 1989 mengenai Persetujuan Tindakan Medik, maka yang berhak memberikan persetujuan atau menandatangani perjanjian adalah pasien yang sudah dewasa (di atas 21 tahun atau sudah menikah) dan dalam keadaan sehat mental. Sedapat mungkin Persetujuan Tindakan Medis ditandatangani sendiri oleh pasien. Namun dalam praktek di lapangan Persetujuan Tindakan Medis lebih sering ditandatangani oleh keluarga pasien. Hal ini berkaitan dengan kesiapan mental pasien untuk menjalani tindakan medik maupun untuk menandatangani Persetujuan Tindakan Medis tersebut. Untuk pasien di bawah umur 21 tahun dan pasien dengan gangguan jiwa maka yang menandatangani Persetujuan Tindakan Medis adalah orang tua atau keluarga terdekat atau walinya. Untuk pasien yang tidak sadar, pingsan atau tidak didampingi oleh keluarga terdekat dan secara medis dalam keadaan gawat darurat dan perlu dilakukan tindakan segera atau yang bersifat menyelamatkan kehidupan tidak diperlukan persetujuan.

Dalam rangka menjaga kemanan dan kesahihan Persetujuan Tindakan Medis diperlukan saksi dari pihak keluarga maupun dari rumah sakit. Mengenai jumlahnya tidak ada pedoman khusus, namun biasanya ada 2 orang, yaitu satu mewakili pasien dan satu mewakili rumah sakit. Tetapi hal ini tidak mutlak, dapat saja dua-duanya dari pihak keluarga ataupun dari rumah sakit (FKUI, 2007).

Menurut Konsil Kedokteran Indonesia ${ }^{15}$ yang dapat memberikan persetujuan adalah individu yang kompeten, ditinjau dari usia maka seseornag dianggap kompeten apabila telah berusia 18 tahun atau lebih atau telah pernah menikah. Sedangkan anak-anak yang berusia 16 tahun atau lebih tetapi belum berusia 18 tahun dapat membuat persetujuan tindakan kedokteran tertentu yang tidak berisiko apabila mareka dapat menunjukkan kompetensinya dalam membuat keputusan.

Suatu persetujuan tindakan medis atau informed consent dianggap sah apabila pasien telah diberi penjelasan/informasi, pasien atau yang sah mewakilinya dalam keadaan cakap (kompeten) untuk memberikan keputusan/persetujuan dan persetujuan harus diberikan secara sukarela. Kadang-kadang orang menekankan pentingnya penandatanganan formulir persetujuan tindakan kedokteran. Meskipun formulis tersebut penting dan sangat menolong dan kadang-kadang diperlukan secara hukum, tetapi penandatanganan formulis itu sendiri tidak mencukupi, yang lebih penting adalah mengadakan diskusi yang rinci dengan pasien dan didokumentasikan di dalam rekam medis.

7. Masa Berlaku Informed Consent

Menurut Konsil Kedokteran Indonesia $(\mathrm{KKI})^{16}$, tidak ada satu ketentuanpun yang mengatur tentang lama keberlakukan suatu persetujuan tindakan kedokteran. Teori menyatakan bahwa suatu persetujuan akan tetap sah sampai dicabut kembali oleh pemberi persetujuan atau pasien. Namun demikian, bila muncul informasi baru, misalnya tentang adanya efek samping atau alternatif tindakan yang baru, maka pasien harus diberitahu dan persetujuannya dikonfirmasikan lagi. Apabila terdapat jeda waktu antara saat pemberian persetujuan hingga dilakukannya tindakan, maka alangkah lebih baik apabila ditanyakan kembali apakah

\footnotetext{
${ }^{14}$ FKUI. 2007. Persetujuan Tindakan Medik (Informed Consent). Retrieved Desember 28, 2007. from http://fkuii.org/tiki-download_wiki_attachment.php

${ }^{15}$ Konsil Kedokteran Indonesia. 2006. Manual Persetujuan Tindakan Medis. Edisi I. Jakarta : Konsil kedokteran Indonesia

${ }^{16}$ Konsil Kedokteran Indonesia, op. Cit., hal 17
} 
persetujuan tersebut masih berlaku. Hal-hal tersebut pasti juga akan membantu pasien terutama bagi mereka yang sejak awal memang masih ragu-ragu atau masih memiliki pertanyaan.

8. Format Informed Consent.

Menurut Konsil Kedokteran Indonesia ${ }^{17}$ format persetujuan tindakan kedokteran harus mencakup atau berisi antara lain :

1) Dokter pelaksana tindakan

2) Pemberi informasi

3) Penerima informasi/pemberi persetujuan

a. Jenis informasi yang meliputi : Diagnosis (WD \& DD), Dasar diagnosis, Tindakan kedokteran, Indikasi tindakan, Tata cara tindakan, Tujuan tindakan, Risiko tindakan, komplikasi dari tindakan, prognosis dan alternatif dan risiko tindakan yang lain.

b. Pernyataan dari dokter yang memberikan infomasi, bahwa telah memberikan informasi secara benar dan jelas dan memberikan kesempatan untuk bertanya atau berdiskusi yang disertai kolom tanda tangan.

c. Pernyataan dari yang menerima informasi, bahwa telah menerima informasi sebagaimana yang diberikan pemberi informasi dan kolom tanda tangan untuk penerima informasi.

d. Identitas pemberi persetujuan yang meliputi: nama, umur, jenis kelamin dan alamat.

e. Pernyataan persetujuan terhadap tindakan yang akan dilakukan oleh dokter terhadap nama, hubungan kekerabatan, umur, jenis kelamin dan alamat.

f. Tempat, tanggal, bulan, tahun dan jam dibuat.

g. Tanda dan nama terang yang memberikan pernyataan dan nama serta tanda tangan dua orang saksi.

\section{Aspek Hukum Informed Consent Sebagai Rekam Medis}

Dalam hubungan hukum, pelaksana dan pengguna jasa tindakan medis (dokter dan pasien) bertindak sebagai "subyek hukum" yakni orang yang mempunyai hak dan kewajiban, sedangkan "jasa tindakan medis" sebagai "obyek hukum" yakni sesuatu yang bernilai dan bermanfaat bagi orang sebagai subyek hukum, dan akan terjadi perbuatan hukum yaitu perbuatan yang akibatnya diatur oleh hukum, baik yang dilakukan satu pihak saja maupun oleh dua pihak ${ }^{18}$. Dalam masalah "informed consent" dokter sebagai pelaksana jasa tindakan medis, disamping terikat oleh KODEKI (Kode Etik Kedokteran Indonesia) bagi dokter, juga tetap tidak dapat melepaskan diri dari ketentuan-ketentuan hukum perdata, hukum pidana maupun hukum administrasi, sepanjang hal itu dapat diterapkan.

Pada pelaksanaan tindakan medis, masalah etik dan hukum perdata, tolok ukur yang digunakan adalah "kesalahan kecil" (culpa levis), sehingga jika terjadi kesalahan kecil dalam tindakan medis yang merugikan pasien, maka sudah dapat dimintakan pertanggungjawabannya secara hukum. Hal ini disebabkan pada hukum perdata secara umum berlaku adagium "barang siapa merugikan orang lain harus memberikan ganti rugi". Sedangkan pada masalah hukum pidana, tolok ukur yang dipergunakan adalah "kesalahan berat" (culpa lata). Oleh karena itu adanya kesalahan kecil (ringan) pada pelaksanaan tindakan medis belum dapat dipakai sebagai tolok ukur untuk menjatuhkan sanksi pidana Aspek Hukum Perdata Informed Consent.

${ }^{17}$ Konsil Kedokteran Indonesia. 2006. IBID, LOC CIT, d

18 Irwandy, 2007. Mengenal"Informed Consent". retrieved November 1, 2007. from http://irwandykapalawi.wordpress.com/2007/11/01/mengenal-informed-consent/ 
Informed Consent merupakan alat bukti yang penting dalam hukum perdata, karena informed consent merupakan bukti tulisan tentang suatu peristiwa dalam hal ini informed yang dilakukan oleh dokter kepada pasiennya dan ditandatangani oleh pasien atau yang berhak. Hal tersebut sesuai dengan apa yang disebut akta (akta di bawah tangan), bahwa akte adalah suatu tulisan yang sengaja dibuat untuk dijadikan bukti tentang suatu peristiwa dan ditandatangani. ${ }^{19}$ Mencermati apa yang disampaikan oleh Subekti di atas, maka menurut peneliti, suatu tulisan tersebut ditulis terlebih dahulu dan bermakna tentang suatu peristiwa dan disepakati oleh pihak yang menandatangani. Oleh karena itu suatu tulisan yang tidak lengkap sehingga kurang bermakna tentang suatu peristiwa akan tidak bermakna pula sebagai bukti hukum, karena tidak memenuhi kaidah-kaidah sebagai akta dibawah tangan. Sementara sesuai dengan bunyi KUHPerdata Pasal 1867: "Pembuktian dengan tulisan dilakukan dengan tulisan-tulisan otentik maupun dengan tulisan-tulisan di bawah tangan". Tulisan-tulisan di bawah tangan tersebut tentu harus sesuai dengan kaidah-kaidah akte di bawah tangan sesuai yang disampaikan oleh Subekti ${ }^{20}$

Suatu tindakan medis yang dilakukan oleh pelaksana jasa tindakan medis (dokter) tanpa adanya persetujuan dari pihak pengguna jasa tindakan medis (pasien), sedangkan pasien dalam keadaan sadar penuh dan mampu memberikan persetujuan, maka dokter sebagai pelaksana tindakan medis dapat dipersalahkan dan digugat telah melakukan suatu perbuatan melawan hukum (onrechtmatige daad) berdasarkan Pasal 1365 KUHPerdata, yaitu " Tiap perbuatan melanggar hukum, yang membawa kerugian kepada seorang lain, mewajibkan orang yang karena salahnya menerbitkan kerugian itu, mengganti kerugian tersebut".

Pelanggaran hukum yang terkait dengan informed Consent dalam tindakan medis berdasarkan UUPK No. 29 tahun 2004 Pasal 45 (5) Setiap tindakan kedokteran atau kedokteran gigi yang mengandung resiko tinggi harus diberikan dengan persetujuan tertulis yang ditandatangani oleh yang berhak memberikan persetujuan. Hal ini karena pasien mempunyai hak atas tubuhnya, sehingga dokter harus menghormatinya. Oleh karena itu tidak memberikan informed Consent pada suatu tindakan medis yang beresiko tinggi adalah suatu perbuatan melawan hukum. Hal tersebut sesuai dengan bunyi KUHPerdata Pasal 1233 yaitu " Tiap-tiap perikatan dilahirkan baik karena persetujuan, baik karena Undang-undang, dan Pasal 1234 yang berbunyi " Tiap-tiap perikatan adalah untuk memberikan sesuatu, untuk berbuat sesuatu atau untuk tidak berbuat sesuatu. Uraian diatas menunjukan bahwa seorang dokter berkewajiban memberikan informed consent karena terikat oleh Undang-undang, sehingga apabila tidak memberikan informed consent maka seorang dokter telah melakukan perbuatan melanggar hukum.

Aspek Hukum Pidana "informed consent" mutlak harus dipenuhi dengan adanya pasal 351 Kitab Undang-Undang Hukum Pidana (KUHP) tentang penganiayaan antara lain berbunyi (1) Penganiayaan diancam dengan pidana penjara paling lama dua tahun delapan bulan atau denda paling banyak empat ribu lima ratus rupiah (2) Jika perbuatan mengakibatkan luka berat, yang bersalah diancam paling lama penjara selama lima tahun (3) Jika mengakibatkan mati, diancam penjara paling lama tujuh tahun. Suatu tindakan invasive (misalnya pembedahan, tindakan radiology invasive) yang dilakukan pelaksana jasa tindakan medis tanpa adanya izin dari pihak pasien, maka pelaksana jasa tindakan medis dapat dituntut telah melakukan tindak pidana penganiayaan yaitu telah melakukan pelanggaran terhadap Pasal $351 \mathrm{KUHP}^{21}$

19 Subekti, 1993. Hukum Pembuktian, PT. Pradnya Paramita, Jakarta

20 Subekti, 1993, op. Cit hal 22

21 Irwandy, 2007. Mengenal"Informed Consent". retrieved November 1, 2007. from http://irwandykapalawi.wordpress.com/2007/11/01/mengenal-informed-consent/ 
10. Kelengkapan Formulir Informed Consent sebagai rekam medis

Menurut Sanjoyo ${ }^{22}$ maksud dari aspek hukum adalah mempunyai nilai hukum dan isinya menyangkut masalah adanya jaminan kepastian hukum atas dasar keadilan dalam rangka usaha menegakkan hukum serta penyediaan bahan tanda bukti untuk menegakkan keadilan. Sedangkan Rekam medis yang bermutu adalah. Akurat, menggambarkan proses dan hasil akhir pelayanan yang diukur secara benar

a. Lengkap, mencakup seluruh kekhususan pasien dan sistem yang dibutuhkan dalam analisis hasil ukuran.

b. Terpercaya, dapat digunakan dalam berbagai kepentingan.

c. Valid atau sah sesuai dengan gambaran proses atau produk hasil akhir yang diukur.

d. Tepat waktu, dikaitkan dengan episode pelayanan yang terjadi.

e. Dapat digunakan untuk kajian, analis, dan pengambilan keputusan.

f. Seragam, batasan sebutan tentang elemen data yang dibakukan dan konsisten penggunaaannya di dalam maupun di luar organisasi.

g. Dapat dibandingkan dengan standar yang disepakati diterapkan.

h. Terjamin kerahasiaannya.

i. Mudah diperoleh melalui sistem komunikasi antar yang berwenang.

j. Menurut Sanjoyo ${ }^{23}$ beberapa kewajiban pokok yang menyangkut isi informed consent sebagai rekam medis yang berkaitan dengan aspek hukum adalah:

1. Segala gejala atau peristiwa yang ditemukan harus dicatat secara akurat dan langsung;

2. Setiap tindakan yang dilakukan tetapi tidak ditulis, secara yuridis dianggap tidak dilakukan;

3. Rekam medis harus berisikan fakta dan penilaian klinis;

4. Setiap tindakan yang dilakukan terhadap pasien harus dicatat dan dibubuhi paraf;

5. Tulisan harus jelas dan dapat dibaca (juga oleh orang lain);

6. Kesalahan yang diperbuat oleh tenaga kesehatan lain karena salah baca dapat berakibat fatal;

7. Tulisan yang tidak bisa dibaca, dapat menjadi bumerang bagi si penulis, apabila rekam medis ini sampai ke pangadilan;

8. Jangan menulis tulisan yang bersifat menuduh atau mengkritik teman sejawat atau tenaga kesehatan yang lainnya;

9. Jika salah menulis, coretlah dengan satu garis dan diparaf, sehingga yang dicoret masih bisa dibaca;

10.Jangan melakukan penghapusan, menutup dengan tip-ex atau mencorat coret sehingga tidak bisa dibaca ulang;

11. Bila melakukan koreksi di komputer, diberi space untuk perbaikan tanpa menghapus isi yang salah;

12. Jangan merubah catatan rekam medis dengan cara apapun karena bisa dikenai pasal penipuan.

Menurut Anny Isfandyarie ${ }^{24}$, Informed Consent adalah hubungan antara dokter dengan pasien yang terjalin dalam transaksi terapeutik menimbulkan kewajiban masing-masing pihak

22 Sanjoyo,R. 2007. Aspek Hukum Rekam Medis. Retrieved Desember 28, 3007, from http://yoyoke.web.ugm.ac.id/download/aspekhukumrekam medis.pdf

23 Sanjoyo,R. 2007. Aspek Hukum Rekam Medis. Retrieved Desember 28, 3007, from http://yoyoke.web.ugm.ac.id/download/aspek hukum rekam medis.pdf

24 Any Isfandyarie, 2006 Tanggung Jawab Hukum dan Sanksi bagi Dokter, Jakarta : Prestasi Pustaka, halaman... 
yaitu pihak pemberi pelayanan (medical providers) dan pihak penerima pelayanan (medical receivers), dan harus dihormati oleh para pihak.

Menurut J. Guwandi KUHP Perdata Pasal 1321 : suatu persetujuan tidak mempunyai nilai hukum jika diberikan karena kekhilafan, karena diancam dengan kekerasan, atau diperolehnya dengan tipuan.Informasi harus diberikan dengan iktikad baik, secara jujur, dan bersifat tidak menakut-nakuti atau memaksa.

Suatu tindakan medis yang dilakukan dengan suatu keahlian tingkat tinggi dan dilakukan sebagai upaya penyelamatan yang mutlak perlu pun akan tetap dianggap sebagai tindak pidana penganiayaan sebagaimana ditentukan dalam pasal $351 \mathrm{KUHP}$ bilamana tanpa didasari atas Informed Consent. ${ }^{11}$

Informed consent dapat didefinisikan sebagai persetujuan yang diberikan oleh pasien dan atau keluarganya atas dasar penjelasan mengenai tindakan medis yang akan dilakukan terhadap dirinya serta resiko yang berkaitan dengannya yang mana memenuhi unsur, keterbukaan informasi yang cukup diberikan oleh dokter, kompetensi pasien dalam memberikan persetujuan, kesukarelaan (tanpa paksaan atau tekanan) dalam memberikan persetujuan. ${ }^{11}$

Dilihat dari segi hukum pidana masalah informed consent lebih ditekankan pada masalah consent atau persetujuannya. Suatu tindakan medis invasive khususnya, harus didasarkan pada persetujuan pasien. Tanpa adanya persetujuan dari pasien maka dokter yang melakukan tindakan medis itu (misalnya melakukan operasi) dapat dipersalahkan karena telah melakukan tindakan pidana penganiayaan sebagaimana diatur dalam Pasal 351 KUHP, terlebih lagi dalam tindakan medis itu juga dilakukan pembiusan. Namun menurut Leene, bila Dokter tersebut telah memenuhi 3 syarat, maka ia tidak dapat dituntut atas dasar Pasal 351 KUHP tersebut. Adapun ketiga syarat tersebut adalah :

1. Orang yang dilukai itu memberikan persetujuan;

2. Tindakan medik tersebut berdasarkan suati indikasi medik dan ditujukan pada suatu tujuan yang kongkrit;

3. Tindakan medik itu dilakukan sesuai ilmu kedokteran.

Berdasarkan Pasal 170 KUHP:

(1) Barang siapa dengan terang-terangan dan dengan tenaga bersama menggunakan kekerasan terhadap orang atau barang, diancam dengan pidana penjara paling lama lima tahun enam bulan.

(2) Yang bersalah diancam:

1. dengan pidana penjara paling lama tujuh tahun, jika ia dengan sengaja menghancurkan barang atau jika kekerasan yang digunakan mengakibatkan lukaluka;

2. dengan pidana penjara paling lama sembilan tahun, jika kekerasan mengakibatkan luka berat;

3. dengan pidana penjara paling lama dua belas tahun, jika kekerasan mengakibatkan maut.

Pasal 351 KUHP menyebutkan :

(1) Penganiayaan diancam dengan pidana penjara paling lama dua tahun delapan bulan atau pidana denda paling banyak empat ribu lima ratus rupiah,

(2) Jika perbuatan mengakibatkan luka-luka berat, yang bersalah diancam dengan pidana penjara paling lama lima tahun.

(3) Jika mengakibatkan mati, diancam dengan pidana penjara paling lama tujuh tahun.

(4) Dengan penganiayaan disamakan sengaja merusak kesehatan.

(5) Percobaan untuk melakukan kejahatan ini. 
(3) Jenis-jenis perjanjian yang ada relavansinya dengan Informed Consent adalah jenis-jenis perjanjian menurut Djaja S. Meliala ${ }^{25}$ antara lain :

a. Perjanjian Konsensual dan Riil

Perjanjian konsensual adalah perjanjian yang timbul (lahir) karena kata sepakat para pihak, sedang dalam perjanjian riil, kata sepakat para pihak terjadi bersamaan dengan penyerahan (levering) barangnya.

b. Perjanjian Formil

Perjanjian formil adalah perjanjian yang harus dibuat secara tertulis, jika tidak maka perjanjian ini menjadi batal.

c. Perjanjian Standar/baku (standard contract)

Peranjian standar bentuknya tertulis berupa formulir-formulir yang isinya telah distandarisasi (dibakukan) terlebih dulu secara sepihak oleh produsen, serta bersifat masal, tanpa mempertimbangkan perbedaan kondisi yang dimiliki oleh konsumen.

11. Syarat Sahnya Suatu Perjanjian

Informed Consent dalam tindakan asuhan keperawatan menurut Permenkes Nomor 148 tahun 2010 Pasal 12 ayat 1 (a) menghormati hak pasien, (d) memberikan informasi tentang masalah kesehatan pasien/klient dan pelayanan yang dibutuhkan, (e) meminta persetujuan tindakan keperawatan yang akan dilakukan.

\section{Dampak Tidak Adanya Informed Consent}

Menurut Konsil Kedokteran Indonesia ${ }^{26}$ jika sesorang dokter tidak memperoleh persetujuan tindakan kedokteran yang sah, maka dampaknya adalah bahwa dokter tersebut akan dapat mengalami masalah antara lain :

a. Hukum Pidana

Menyentuh atau melakukan tindakan terhadap pasien tanpa persetujuan dapat dikategorikan sebagai "penyerangan" (assault). Hal tersebut dapat menjadi alasan pasien untuk mengadukan dokter ke peyidik polisi, meskipun kasus semacam ini sangat jarang terjadi.

Aspek Hukum Pidana "informed consent" mutlak harus dipenuhi dengan adanya pasal 351 Kitab Undang-Undang Hukum Pidana (KUHP) tentang penganiayaan antara lain berbunyi (1) Penganiayaan diancam dengan pidana penjara paling lama dua tahun delapan bulan atau denda paling banyak empat ribu lima ratus rupiah (2) Jika perbuatan mengakibatkan luka berat, yang bersalah diancam paling lama penjara selama lima tahun (3) Jika mengakibatkan mati, diancam penjara paling lama tujuh tahun. Suatu tindakan invasive (misalnya pembedahan, tindakan radiology invasive) yang dilakukan pelaksana jasa tindakan medis tanpa adanya izin dari pihak pasien, maka pelaksana jasa tindakan medis dapat dituntut telah melakukan tindak pidana penganiayaan.

b. Hukum Perdata

Untuk mengajukan tuntutan atau klaim ganti rugi terhadap dokter, maka pasien harus dapat menunjukkan bahwa dia tidak diperingatkan sebelumnya mengenai hasil akhir tertentu dari tindakan dimaksud padahal apabila dia telah diperingatkan sebelumnya maka dia tentu tidak akan mau menjalaninya, atau menunjukkan bahwa dokter telah melakukan tindakan tanpa persetujuan (perbuatan melanggar hukum).

25 Djaja S. Meliala, 2007. Perkembangan Hukum Perdata Tentang Benda dan Hukum Periktanan, Nuansa Aulia, Bandung.

26 Konsil Kedokteran Indonesia. 2006. Manual Persetujuan Tindakan Medis. Edisi I. Jakarta : Konsil kedokteran Indonesia. 
Hal tersebut sesuai KUHPerdata Pasal 1234 yang berbunyi : "Tiap-tiap perikatan adalah untuk memberikan sesuatu, untuk berbuat sesuatu atau untuk tidak berbuat sesuatu. Maka apabila tidak berbuat sesuatu dalam hal ini memberikan Informed Consent maka dapat dikatakan telah melakukan perbuatan melawan hukum karena ingkar janji atau wanprestasi."

Tanggung jawab perdata dokter karena perbuatan melawan hukum (onrechtmatig daad) adalah dapat dituntut berdasarkan KUH Perdata Pasal 1365: "Tiap perbuatan melanggar hukum, yang membawa kerugian kepada seorang lain, mewajibkan orang yang karena salahnya menerbitkan kerugian itu, mengganti kerugian tersebut".

\section{c. Pendisiplinan oleh MKDKI}

Bila MKDKI menerima pengaduan tentang seorang dokter atau dokter gigi yang melakukan hal tersebut, maka MKDKI akan menyidangkan dan dapat memberikan sanksi disiplin kedokteran, yang dapat berupa teguran hingga rekomendasi pencabutan Surat Tanda Resgistrasi.

Menurut Soeraryo Darsono ${ }^{27}$ penerapan hukum kedokteran berdasarkan Pasal 1239 KUHPerdata menyatakan bahwa dokter dapat dituntut secara perdata apabila; melakukan wanprestasi atau ingkar janji, wanprestasi tersebut juga termasuk tidak memberikan informed consent dalam suatu tindakan medis.

Sedangkan menurut Brunner dan Suddarth ${ }^{28}$ informed consent adalah untuk melindungi pasien terhadap pembedahan yang lalai dan melindungi ahli bedah terhadap tuntutan dari suatu lembaga hukum.

Sementara ditinjau dari KUHPidana Pasal 354, ayat (1) Barangsiapa sengaja melukai berat orang lain, diancam karena melakukan berat dengan pidana penjara paling lama delapan tahun (2) Jika perbuatan itu mengakibatkan kematian, yang bersalah diancam dengan pidana penjara paling lama sepuluh tahun.

Terkait juga dengan dampak ketidak adanya informed consent adalah KUHPidana Pasal 359 adalah "Barang siapa karena kesalahannya atau kealpaannya menyebabkan orang lain mati, diancam dengan pidana penjara lima tahun atau pidana kurungan paling lama satu tahun".

Sementara ketidak lengkapan informed consent juga dapat dikaitkan dengan pemalsuan surat sesuai dengan bunyi KUHPidana Pasal 263 ayat (1) Barang siapa membuat surat paslu atau memalsukan surat yang dapat menimbulkan suatu hak, perikatan atau pembebasan hutang, atau yang diperuntukan sebagai bukti daripada sesuatu hal yang diperuntukan dengan maksud untuk memakai atau menyuruh orang lain memakai surat tersebut seolah-olah isinya benar dan tidak dipalsu, diancam jika pemakaian tersebut dapat menimbulkan kerugian, karena pemalsuan surat, dengan pidana paling lama enam tahun.

${ }^{27}$ Soeraryo Darsono, 2006. Etik Hukum Kesehatan Kedokteran, Semarang : Bagian Ilmu Kedokteran Forensik \& Medikolegal Fakultas kedokteran Universitas Diponegoro.

28 Brunner \& Suddarth, 2002. Keperawatan Medical Bedah, EGC, JakartaBrunner \& Suddarth, 2002. Keperawatan Medical Bedah, EGC, Jakarta 


\section{KERANGKA BERFIKIR}
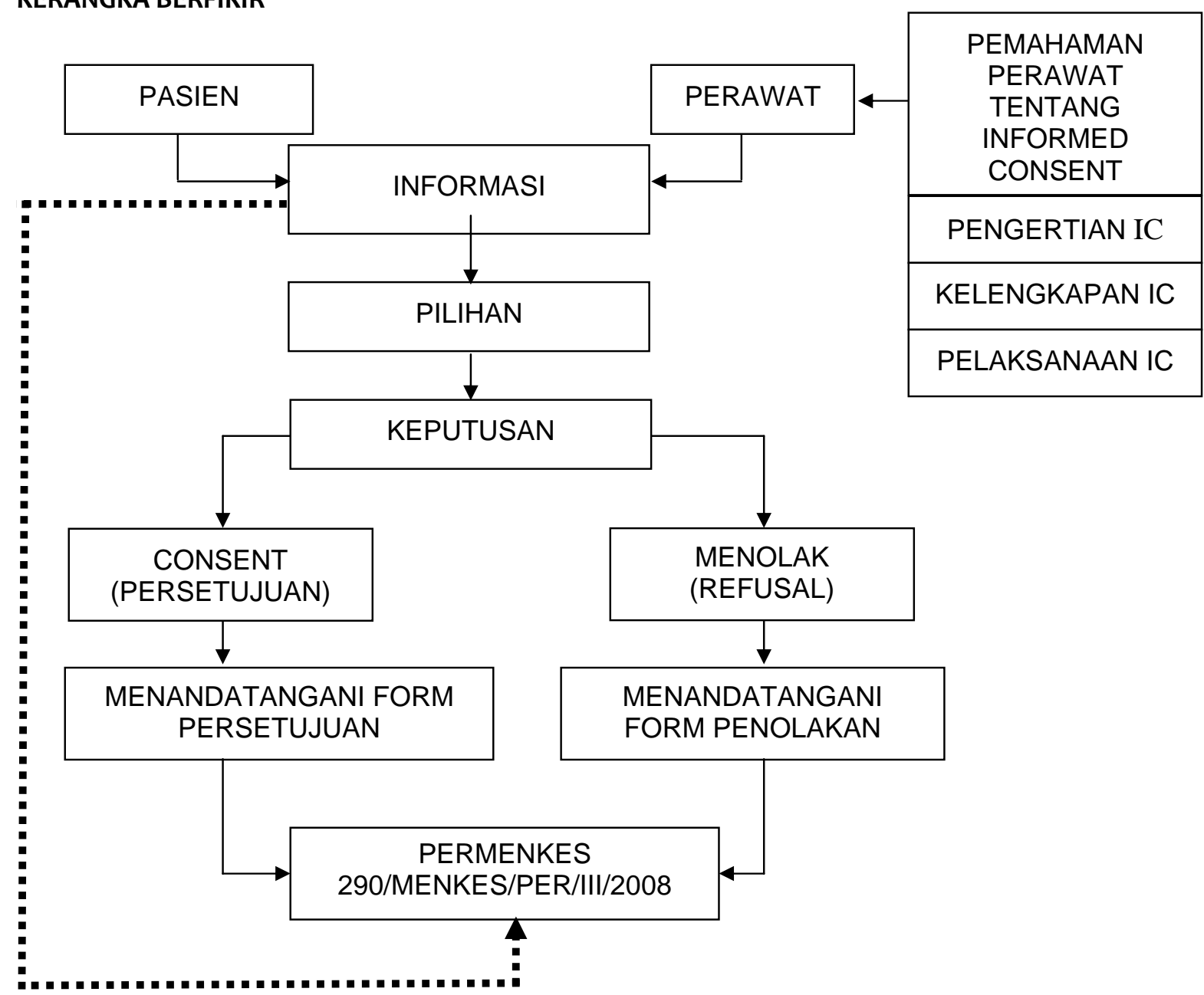

Keterangan

Dari bagan di atas menunjukan jalur yang senantiasa berurutan, pada tahap pertama perawat dengan pasien dihubungkan dengan suatu dialog, forum informasi kemudian terjadi pilihan (choice) dan pengambilan keputusan. Terdapat dua keluaran pengambilan keputusan yaitu menyetujui dan menolak. Hal ini sesuai dengan PERMENKES 290/MENKES/PER/III/2008 dan sesuai dengan hak pasien untuk menentukan diri sendiri yaitu pasien berhak menerima atau menolak tindakan setelah ada penjelasan.

\section{HASIL PENELITIAN}

Skor hasil jawaban responden terhadap pertanyaan kuesner dengan katagori :

Skor baik : apabila responden menjawab kelima pertanyaan dengan benar Skor kurang : apabila responden menjawab pertanyaan benar kurang dari lima pertanyaan. Dari hasil penelitian : 
1. Tingkat pengetahuan tentang informed consent para tenaga perawat yang melaksanakan asuhan keperawatan di RSUD Dr H Soewondo Kendal :

a) Tingkat pengetahuan perawat tentang informed consent dari hasil survy pada 55 responden yang menjawab pertanyaan tentang pengetahuan mengenai informed consent dengan katagori baik 14 responden (25,5\%) sedangkan dengan katagori kurang 41 responden ( 74,5\%).

b) Pengetahuan tentang kelengkapan informed consent menunjukan bahwa dari 55 responden diketahui terdapat 5 responden $(9,1 \%)$ pengetahuan tentang informed consentnya baik, dan yang pengetahuan tentang kelengkapan informed consentnya kurang .

2. Pelaksanaan informed consent oleh tenaga perawat yang melaksanakan asuhan keperawatan di RSUD Dr H Soewondo Kendal, mengenai pelaksanaan informed consent oleh tenaga perawat, 6 responden menjawab pertanyaan dengan benar, sedangkan 49 responden tentang pelaksanaan informed consent kurang

\section{PEMBAHASAN}

Berdasarkan hasil penelitian terbukti latar belakang pendidikan tenaga perawat yg melaksanakan tindakan askep masih didominir oleh D III keperawatan sedangkan yg berlatar belakang $\mathrm{S} I$ keperawatan mempunyai fungsi sbg koordinator perawat di unit-unit rawat nginap

Berdasarkan hasil penelitian ttg pengertian informed consent menunjukan masih kurangnya tenaga perawat ttg pengertian informed consent dengan demikian bila dikaitkan pengetahuan menurut Noto atmojo para tenaga perawat belum memahami ttg informed consent

Pengetahuan perawat ttg kelengkapan ic dari 55 responden yg baik pengetahuannya ttg kelengkapan 5 responden dan yg kurang 50 responden hal ini kelengkapan ttg ic tidak bisa diabaikan konsekuensi ketidak lengkapan ic bisa berkaitan dng aspek hukum baik hukum perdata maupun hukum pidana

Pengetahuan perawat ttg pelaksanaan ic berdasarkan data yg doperoleh dari 55 responden 6 responden yg pengetahuan ttg pelaksanaan ic baik dan 49 pengetahuan ttg pelaksanaan ic kurang sehingga dampaknya menjadi tidak syahnya ic

Secara keseluruhan dari 55 responden pengetahuan ttg pengertian ic, pengetahuan ttg kelengapan ttg ic, dan pengetahuan pelaksanaan ttg ic kurang baik, walaupun ic untuk tindakan askep telah dilaksanakan namun belum sempurna sesuai yg diharapkan

\section{KESIMPULAN}

Berdasarkan hasil penelittian Tingkat Pengetahuan Perawat Tentang Informed Consent bagi Tenaga Perawat yang Melaksanakan Asuhan Keperawatan untuk Pasien yang Dirawat di RSUD Dr. H Soewondo Kendal disimpulkan sebagai berikut :

1. Mengenai pengetahuan tentang informed consent, 14 responden (25,5\%) pengetahuan tentang informed consentnya baik, sedangkan 41 responden (74,5\%) pengetahuan tentang informed consent kurang $\mathrm{Hal}$ ini menunjukan bahwa pengetahuan tenaga perawat tentang informed consent masih kurang/rendah. Dalam pelaksanaan, tindakan asuhan keperawatan tetap dilaksanakan oleh tenaga perawat sehingga apabila pengetahuan perawat tentang informed consent kurang baik, dikhawatirkan dokumen tentang informed consent tidak valid. Hal ini tidak sesuai dengan ketentuan Pasal 45 ayat (5) Undang-undang No. 29 tahun 2004 tentang Praktek Kedokteran. Lima puluh (50) dari ke 55 Responden, kelengkapan informed 
consent masih kurang. Sedangkan 5 responden cukup baik kelengkapan informed consent Dengan demikian dapat disimpulkan bahwa tenaga perawat yang memberikan tindakan asuhan keperawatan pengetahuannya tentang kelengkapan informed consent kurang, hal ini bisa dilihat dalam pendokumentasian informed consent yang tidak dilakukan di blangko informed consent, tetapi di catatan tindakan asuhan keperawatan.

2. Dari aspek hukum perdata bila ketidak kelengkapan informed consent dikaitkan dengan bunyi kitab Undang-Undang Hukum Perdata Pasal 1233 yaitu "Tiap-tiap perikatan dilahirkan baik karna persetujuan, baik karna Undang-Undang", dan Pasal 1234 yang berbunyi : "Tiap-tiap perikatan adalah untuk memberikan sesuatu, untuk berbuat sesuatu atau untuk tidak berbuat sesuatu. Urian diatas menunjukan bahwa seoarang dokter maupun tenaga kesehatan lain (tenaga keperawatan) berkewajiban memberikan informed consent karena terikat oleh undang-undang, sehingga apabila tidak memberikan informed consent maka seorang dokter, tenaga keperawatan maupun tenaga kesehatan lain telah melakukan perbuatan melanggar hukum, maka para pemberi pelayanan tidakan tersebut tidak bisa digunakan sebagai pertanggungan jawaban atas pelaksanaan informed consent terhadap pasien dan bisa menimbulkan permasalahan hukum.

3. Data tentang pelaksanaan informed consent oleh tenaga perawat di RSUD Dr. H. Soewondo Kendal menunjukkan sebagian besar kurang baik, yaitu 49 responden (89,1\%) dari 55 responden. Dan hanya 6 responden $(10,9 \%$ ) yang berpendapat bahwa informed consent dilaksanakan secara baik. Dengan demikian dapat disimpulkan bahwa pelaksanaan informed consent pada tindakan asuhan keperawatan di RSUD Dr. H. Soewondo Kendal dilakukan secara kurang baik. Dalam melaksanakan tindakan asuhan keperawatan, para perawat mendahulukan tindakan asuhan keperawatan terlebih dahulu, berikutnya baru memberikan informasi dan persetujuan kepada siapa saja - baik pasien itu sendiri maupun keluarganya yang dianggap bisa memberikan persetujuan. Dampak bila informed consent tidak dilaksanakan sebagaimana mestinya, maka perjanjian yang diadakan dianggap tidak sah. Hal ini tidak sesuai dengan ketentuan Pasal $1321 \mathrm{KUH}$ Perdata yang menyebutkan : "Tiada sepakat yang sah apabila sepakat itu diberikan karena kekhilafan, atau diperolehnya dengan paksaan atau penipuan". Selain itu tidak memenuhi ketentuan Pasal 1337 KUH Perdata yang menjelaskan bahwa suatu perjanjian adalah sah apabila dibuat dengan berdasarkan pada suatu sebab yang tidak berlawanan dengan undang-undang, kesusilaan baik atau ketertiban umum.

4. Dari hasil penelitian terdapat temuan bahwa ke-55 responden dari aspek tingkat pengetahuan tentang informed consent, kelengkapan informed consent, dan pelaksanaan informed consent kurang baik. Hal ini tampak dari data yang diperoleh, bahwa tidak ada satupun responden yang dapat menjawab secara benar keseluruh pertanyaan. Risiko apabila suatu tindakan invasive maupun tindakan asuhan keperawatan tanpa adanya informed consent, maka pelaksana jasa tindakan tersebut maka tindakan tersebut dapat dikategorikan sebagai tindak pidana penganiayaan sebagaimana diancam oleh Pasal 351 Kitab UndangUndang Hukum Pidana (KUHP).

\section{SARAN}

1. Bagi RSUD Dr H.Soewondo Kendal, perlunya melakukan review dan sosialisasi tentang konsep dan pemahaman informed consent kepada para perawat tentang kompetensi ,kepada pimpinan rumasakit hasil penelitian ini dapat digunakan untuk mengendalikan mutu pelayanan kesehatan yang telah diberikan dan memonetor serta mengeevaluasi sejauh mana informed consent telah diterapkan di rumah sakit yang dipimpinnya serta untuk menentukan langkahlangkah yang akan diambil dalam meningkatkan kualitas informed consent. 
2. Perlunya ketersedian blangko informed consent yang lengkap dan memadai agar dalam melasanakan tindakan asuhan keperwatan terdukumentasi dengan valid.

\section{DAFTAR PUSTAKA}

Ali, Zaidin, 1998. Dasar-Dasar Keperawatan Profisional, Widya Medika, Jakarta, 2001

Any Isfandyarie,2006 Tanggung Jawab Hukum dan Sanksi bagi Dokter, Prestasi Pustaka,Jakarta

Brunner \& Suddarth, 2002. Keperawatan Medical Bedah, EGC, JakartaBrunner \& Suddarth, 2002. Keperawatan Medical Bedah, EGC, Jakarta

Djaja S. Meliala, 2007. Perkembangan Hukum Perdata Tentang Benda dan Hukum Periktanan, Nuansa Aulia, Bandung

Hery Purwanto 1994 Pengantar Statistik Keperawatan EEG Jakarta

J Guwandi, 1997 Dokter Pasien, Hukum Kedokteran Jakarta Fakultas Kedokteran Universitasa Indonesia

Konsil Kedokteran Indonesia. 2006. Manual Persetujuan Tindakan Medis. Edisi I. Jakarta : Konsil kedokteran Indonesia.

Notoadmodjo, Soekidjo. Pendidikan dan perilaku. Jakarta : Rineka Cipta. 2003

Sanjoyo,R. 2007. Aspek Hukum Rekam Medis. Retrieved Desember 28, 3007, from http://yoyoke.web.ugm.ac.id/download/aspekhukumrekam medis.pdf

Sari, D.P, 2002. Eksistensi Formulir Informed consent dalam pelaksanaan Tindakan Operasi Medik Dilahat Dari Sigi Hukum Perjanjian. Retrieved Juli 22, 2007 fromhttp://digilib.uniko.ac/go.php.id

Soeraryo Darsono, 2006. Etik Hukum Kesehatan Kedokteran, Bagian Ilmu Kedokteran Forensik \& Medikolegal Fakultas kedokteran Universitas Diponegoro, Semarang

Subekti, 1993. Hukum Pembuktian, PT. Pradnya Paramita, Jakarta

Soekidjo Notoatmodjo 2005 Metodologi Penelitian Kesehatan PT Rineka Cipta Jakarta

Undang-undang No.36 tahun 2009 tentang Kesehatan

Undang-undang No 4 tahun 2009 tentang Rumah Sakit.

Keputusan Menteri Kesehatan Nomor. 123/MENKES/SK/XI/2001 tentang Registrasi dan Praktik Perawat.

Peraturan Menteri Kesehatan Republik Indonesia Nomor 290/MENKES/PER/III/2008 tentang Persetujuan Tindakan Kedokteran.

Peraturan Pemerintah no. 32 tahun 1996 tentang Tenaga Kesehatan.

Kepmenkes 1239/2001 dan Keputusan Direktur jendral Pelayanan Medik nomor Y.M.00.03.2.6.956 yang ditetapkan di Jakarta pada tanggal 19 Oktobr 1998.

Perturan Bupati Kendal nomor 40 tentang Peraturan internal RSUD Dr H Soewondo Kendal ( Hospital By Law).

Surat Keputusan Direktur RSUD Dr. H. Soewondo Kendal nomor 441.6/051/RSUD/2008 tentang standar opersional prosedur tindakan keperawatan

FKUI. 2007. Persetujuan Tindakan Medik (Informed Consent). Retrieved Desember 28, 2007. from http://fkuii.org/tiki-download_wiki_attachment.php 
Hidayat, T. 2007. Perlu Diungkap Hak dan Kewajiban Pasien . Retrieved Desember 28, 2007. from http://www.duniaesai.com/hukum/hukumg.html

Indradi, R. 2007. Informed Consent, Hak-Hak Pasien dalam Menyatakan Persetujuan Rencana Tindakan Medis. Retrieved Januari 25, 2007. from http://ranocenter.blogspot.com/2007_01_01_archive.html

Irwandy, 2007. Mengenal"Informed Consent". retrieved November 1, 2007. from http://irwandykapalawi.wordpress.com/2007/11/01/mengenal-informed-consent/

Iswandari, H.D. 2007. Aspek Hukum Penyelenggaraan Praktik Kedokteran: Suatu Tinjauan Berdasarkan Undang-Undang no. 9/2004 Tentang Praktik Kedokteran. Retrieved Juli 30, 2007. from http://catatan-dini.blogspot.com/2007/07/aspek-hukum-penyelenggaraanpraktik.html

Jacobalis,S.2005 Informed Consent Persetujuan Tindakan Medis .Retrived Juni 24,2005 from:http://www.sinarharapan.co.id/iptek/kesehatan/2005/0624/kes3.html

Kasimin, 2007. Modul Hukum Kesehatan, Pokok Bahasan Malpraktek Keperawatan Retrived Desember 28, 2007 from http://www.jmpk-online.net/files/iii.mk.hargian.pdf. 